\title{
Sexual Wellbeing in Early Adolescence: A Cross-sectional Assessment Among Girls and Boys in Urban Indonesia
}

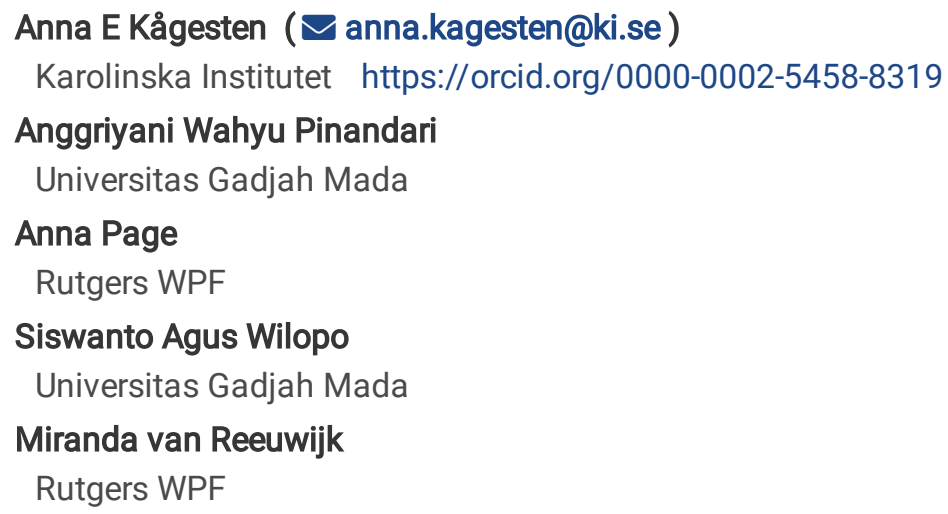

Keywords: Sexual wellbeing, Healthy sexuality, Sexual and Reproductive Health and Rights, Early adolescence, Young people, Asia Posted Date: March 23rd, 2021

DOI: https://doi.org/10.21203/rs.3.rs-345973/v1

License: (c) (i) This work is licensed under a Creative Commons Attribution 4.0 International License. Read Full License

Version of Record: A version of this preprint was published at Reproductive Health on July 20th, 2021. See the published version at https://doi.org/10.1186/s12978-021-01199-4. 


\section{Abstract}

Background: Early adolescence (ages 10-14) is a critical period of physical, cognitive, social and emotional development, which affect sexual and reproductive health and rights. Yet, little is known about positive or healthy aspects of sexuality development during this period of life, especially in South East Asia where sexual norms remain restrictive. The objective of this study is to assess the prevalence and correlates of sexual wellbeing among early adolescent girls and boys ages in Indonesia.

Methods: Data for this cross-sectional study were collected as part of the Global Early Adolescent Study via a school-based survey in three Indonesian urban sites in 2018 ( $\mathrm{N}=4309)$. We assessed the prevalence of multiple indicators of sexual wellbeing (e.g. sexual and reproductive health knowledge and communication, gender attitudes, body satisfaction, self-efficacy, freedom from violence) and tested for differences by gender using Chi-square, Student t-test, and Wilcoxon rank-sum test. Multivariable logistic regression models were used to assess the adjusted odds ratio of selected indicators in relation to sociodemographic factors, romantic and sexual experiences.

Results: The mean age of students was 12 years (53\% girls); $90 \%$ had started puberty. Sexual and reproductive health knowledge and communication was low overall, but higher among boys than girls. Boys were more likely than girls to report high body satisfaction, less feelings of sexual guilt, but also to experience physical peer violence. In contrast, girls were more likely to hold gender equal attitudes, greater self-efficacy to say no, and to report being bullied by boys. In multivariable models, romantic experiences, perceived voice (boys and girls) and decision-making (girls) were associated with three or more indicators of sexual wellbeing.

Conclusions: While young adolescents in Indonesia score high on some aspects of sexual wellbeing, misconceptions, feelings of guilt and uncertainties related to sexuality are common, with clear gender differences. These findings confirm the need for comprehensive sexuality education that begins early in adolescence.

\section{Plain English Summary}

Ages 10-14 years, known as early adolescence, is a fundamental time when young people become increasingly aware of their bodies, gender and sexuality. Yet, little is known about positive or healthy aspects of sexuality development during this period of life, as most studies tend to focus on risks such as teenage pregnancy and sexually transmitted infections. In this study, we conducted a survey with primary school students aged 10-14 years in Indonesia, asking them about sexual wellbeing from a broad sense, such as their body image and knowledge about sexual and reproductive health. We analyzed responses from 4309 participants using statistical methods and compared the results between boys and girls. We found that misconceptions, feelings of guilt and lack of knowledge were common, with clear differences between boys and girls. Our study provides new information about healthy sexuality development in an Asian setting where young people's sexual and reproductive health is often considered taboo. The results can be used to guide programs and research to improve sexual and reproductive health in Indonesia and other low-income settings. In particular, comprehensive sexuality education may play an important role to support sexual wellbeing by providing factual and age-appropriate information as young people grow up.

\section{Background}

In 1994 the International Conference on Population and Development first emphasized the need for countries and governments to invest in adolescent sexual and reproductive health and rights (SRHR) [1]. Since then, the world has seen vast improvements in adolescent SRHR, with significant reductions in teenage pregnancy, child marriage, and female genital mutilation,[2] and increased investments in programs and policies to support adolescents' needs. However, challenges persist, as progress has been patchy across and within countries [2], and adolescent sexuality remains highly stigmatized in many contexts [3].

While addressing these challenges requires a comprehensive approach to SRHR that fully recognizes adolescents' right to their own bodies and to understand their sexuality, research and programs remain almost exclusively focused on risk reduction and negative consequences such as HIV and unintended pregnancy [2]. In contrast, research on positive aspects of adolescent sexuality (e.g., self-esteem, gender attitudes and consensual relationships) is largely missing from a global perspective [4-7]. 
The lack of a positive approach becomes problematic given that sexuality development is a universal, multidimensional process that begins long before a young person has had any sexual interactions [4-7]. Healthy adolescent sexuality development is much more than freedom from disease - it is about building social, emotional and cognitive skills that allow young people to achieve a sense of wellbeing in relation to their bodies, their sexuality and relationships [5]. The formation of such skills is especially critical during early adolescence (ages 10-14 years), which is a period of rapid and interconnected developmental changes that lay the foundation for future health and behaviors [8].

While a small but growing field has attempted to explore different aspects of adolescent sexual wellbeing, most of what we know comes from studies in high-income countries with older youth. Using varying conceptualizations, studies have assessed outcomes such as adolescent's sexual self-concept [9, 10], self-efficacy [9-11], communication [12], attitudes [11, 12], and SRHR knowledge $[10,12]$. Research in low- and middle-income countries is scant, with a few examples predominantly from sub-Saharan Africa, such as a cross-sectional assessment of gender attitudes, self-esteem and body image among 10-14-year-olds in Uganda [13].

In this paper, we focus on the emerging sexual wellbeing of young adolescents in Indonesia, a setting where sexual norms remain restrictive [14]. Nonetheless, evidence indicates that young people in contemporary Indonesia want to, and are, exploring their own sexuality and intimate relationships before marriage. According to the 2018 Indonesian Demographic and Health Survey [15], 98$99 \%$ of never-married $15-19$-year-olds say that women should remain virgins at marriage, and only $0.9 \%$ of never-married girls and $3.6 \%$ of boys report having had sexual intercourse. Meanwhile, $75 \%$ of girls and $78 \%$ of boys had dated someone, with a third starting during early adolescence; and of those who ever dated, up to $56 \%$ of girls and $66 \%$ of boys report non-coital experiences (petting, kissing or holding hands) [15]. A recent qualitative online study with 16-24-year-olds from urban Indonesian communities

further revealed complex patterns by which young people are actively learning about sexuality and how to take care of themselves, while simultaneously embracing dominant (restrictive) norms [14].

We aim to investigate the prevalence and sociodemographic correlates of sexual wellbeing among 10-14-year-old girls and boys residing in three urban regions of Indonesia as part of the Global Early Adolescent Study.

\section{Conceptual framework}

In the current study, we used the conceptual framework for adolescent sexual wellbeing developed by Kågesten and van Reeuwijk [16]. The framework highlights six interrelated domains of competencies in the form of knowledge, attitudes and skills that are central for healthy sexuality development: sexual literacy, gender equal attitudes, respect for human rights and understanding consent, critical reflection skills, coping skills, and interpersonal skills. Together, these competencies have the potential to impede or enhance adolescents' sense of sexual wellbeing both in relation to themselves (e.g. body satisfaction, self-efficacy) and others (e.g. consensual social or sexual interactions). In the current study, we focused on these outcomes to explore gender differences in prevalence and correlates, and use the terms sexual wellbeing and healthy sexuality interchangeably.

\section{Methods}

\section{Study design and context}

We conducted a cross-sectional study as part of the baseline Indonesian arm of the longitudinal Global Early Adolescent Study (GEAS, www.geastudy.org). In Indonesia, the GEAS is part of the Explore4Action quasi-experimental trial evaluating the effect of a comprehensive sexuality education intervention on adolescent SRHR. The project is a collaboration between Rutgers, University Gadjah Mada and the Indonesia Planned Parenthood Association, with support from Johns Hopkins University and Karolinska Institutet. Baseline data were collected in 2018 at intervention and control schools across three sites: Bandar Lampung (Sumatra), Semarang (Java) and Denpasar (Bali), with two follow-ups planned for 2021 and 2022. The sites are predominately urban with different ethnic, cultural, religious and social-economic characteristics. Lampung is a multi-ethnic, Muslim majority city characterized by farming, forestry, mining, fishing, industry and retail. It is generally more Islam conservative than Semarang, which is a Muslim and Javanese majority city predominated by retail, construction and other industries. In contrast, Denpasar is mainly Balinese with Hinduism as main religion, and tourism dominating the economy [17]. 
The study received ethical approval from the Medical Research and Ethics Committee at the Faculty of Medicine, Public Health and Nursing, University Gadjah Mada, and the Johns Hopkins Bloomberg School of Public Health Institutional Review Board for secondary data analysis. We used the STROBE cross-sectional reporting guidelines to guide the development of the current manuscript [18].

\section{Participants and sampling}

For study inclusion, participants had to be aged 10-14 years, in grade 7 at one of the 18 selected schools and provide written parental/guardian consent and their own assent to participate. In each site, three schools were assigned to the intervention, and matched with three nearby control schools with similar characteristics. In total, 4684 boys and girls participated in the baseline survey: 1414 in Lampung, 1517 in Semarang, and 1753 in Denpasar (response rate 75.7\%, 92.8\% and 99\%, respectively) [17].

Of the total sample, 2550 participants had complete data for all 18 sexual wellbeing outcomes assessed, meaning $46.5 \%$ of participants were missing one or more variables, mainly due to "don't know" and "refuse to answer" responses. Most were missing $1(21.3 \%)$ or 2-3 (12.6\%) outcomes, wherefore we coded don't know/refuse as "no" (0) to retain as many as possible. To assure against bias due to recoding, we conducted rigorous sensitivity analyses to compare the distribution in outcomes and covariates when restricting the sample to those with complete data on all outcomes $(\mathrm{N}=2550)$ versus coding don't know/refuse as no $(\mathrm{N}=4309)$. The sensitivity analysis (available upon request) did not indicate any systematic differences in the sample characteristics, with the exception that everyone in the complete case had started puberty and scored higher on a couple of outcomes. This indicated that those participants might have been more experienced and comfortable responding to SRHR questions. Nonetheless, results from bivariate and multivariate analyses were similar for the two approaches. We therefore proceeded with the larger sample of $\mathrm{N}=4309$.

\section{Procedures}

Data for the baseline survey were collected at the schools between August and October 2018 by a team of trained data collectors using computer-assisted self-interviewing via tablets, and computer-assisted personal interviewing for adolescents with low literacy levels. The standardized survey covered sociodemographics, family, peer, school and neighborhood factors, gender attitudes, physical and mental health, puberty, empowerment, violence, romantic relationships, and SRHR. Data were uploaded to a secure server at Universitas Gadjah Mada with regular quality checks. A formal protocol ensured child protection and reporting of child abuse.

\section{Measures}

We included multiple outcome variables across different domains of sexual wellbeing, guided by the conceptual framework. Sexual literacy and communication

HIV and pregnancy knowledge were assessed by aggregating the mean score of 10 correct responses, dichotomized into low and high SRHR knowledge. SRHR communication was assessed by combining five items related to ever having discussed body changes, sexual relationships, pregnancy/contraceptives with someone else.

\section{Gender attitudes}

Three scales developed and validated as part of the GEAS [19] were used to assess perceptions about gender norms, including: 1) sexual double standards (SDS); 2) gender stereotypical traits (GST); and 3) gender stereotypical roles (GSR). Response options ranged from 1 to 5 and were averaged into mean scores (higher $=$ more gender equal attitudes) and dichotomized at the median. We also included a single item measuring agreement with gender-related teasing (e.g. ok to tease a boy who "acts like a girl"). 


\section{Comfort with body and emerging sexuality}

Body satisfaction was assessed via a 4-item, 5-point scale [20], with mean scale scores dichotomized into low vs. high. Pubertal comfort was measured via the item "I like the fact that I am becoming a man/woman", and feelings of guilt in relation to sexuality was assessed using a 3-item, 5-point scale (e.g. perceived guiltiness for looking at oneself naked, being attracted to someone else), with scores dichotomized into low vs. high. A single item measured agreement with whether it is normal for adolescents to be curious about love and sexuality.

\section{Relational self-efficacy}

Measured via two 5-point items about communication of romantic feelings vs. consent, and a 3-item scale assessed self-efficacy to prevent pregnancy with mean scores dichotomized into low vs. high.

\section{Freedom from bullying and violence}

Bullying by peers in the last 6 months was assessed using two items and categorized into no bullying, bullying by both boys/girls, and bullying by the opposite sex only. The same approach was used for physical peer violence. For bullying victims, a dichotomous variable explored whether they thought that this was due to gender or not.

\section{Social-ecological covariates}

These included study site, age, pubertal onset, religion, religiosity, and perceived agency, assessed using two validated 5-point scales [21] to measure voice and decision-making. Sex (boy, girl) was self-reported; for purposes of simplicity we use this interchangeably with gender. Three variables assessed adolescent's relationship status and lifetime experiences of sexual activities. Family variables encompassed main caregiver, household structure and parental connectedness. School/community factors included educational aspirations, number of school days missed last month, whether the adolescent ever felt threatened at school, and access to social media.

(See Appendix Tables 1-2 for a detailed description of all measures).

\section{Statistical analysis}

Following exploratory data analysis, missing values on covariates were imputed using K-nearest neighbor (kNN). We then conducted bivariate analysis using Chi-square, Student t-test, and Wilcoxon rank-sum to compare the prevalence of outcomes by sex. Next, we selected one outcome variable from each sexual wellbeing domain for analysis in relation to covariates based on their relevance to the age group, variation in responses and validity. A series of multivariable logistic regression models were fitted for each of the five outcomes separately for boys vs. girls, guided by backward selection and Akaike's Information Criterion (AIC). All analyses were conducted using STATA version 15.1 (StataCorp. 2017. Stata Statistical Software: Release 15. College Station, TX).

\section{Results}

Of the 4309 participants included in the analysis, $47 \%$ were boys and $53 \%$ girls with mean age 12.2 years (Table 1 ). Ninety percent had started puberty. Most participants reported high religiosity, and over $80 \%$ lived with two parents. Perceived agency varied by sex, with girls expressing higher voice and decision-making than boys. Most participants reported no romantic or sexual experiences, although boys were more likely than girls to report being in a relationship and having non-coital experiences or sexual intercourse (though the latter was very uncommon, $\mathrm{N}=49$ boys, $\mathrm{N}=5$ girls). Girls were more likely than boys to report high parental connectedness, to aspire to complete university and to have missed no school days in the last month, and were less likely than boys to have felt threatened at school. Nine in ten had access to a social media account. 


\section{Prevalence of sexual wellbeing}

Table 2 shows the distribution of the sexual wellbeing indicators by sex and Figure 1 visualizes patterns with focus on positive responses. Knowledge about HIV and pregnancy was low, but higher for boys. Two in three boys and girls reported ever talking with someone else about SRHR; and among those who did so, girls were more likely to have talked about pubertal changes, whereas communication about sexual relationships, pregnancy and contraceptives were more common among boys.

In terms of gender attitudes, both boys and girls had relatively low agreement with sexual double standard norms but higher endorsement of gender-stereotypical traits and roles. Feelings of guilt related to sexuality were very common overall, especially for girls. About half of participants disagreed or were unsure about whether it is normal for adolescents to be curious about love and sexuality.

Boys reported greater self-efficacy to communicate romantic feelings and prevent pregnancy, whereas self-efficacy to reject unwanted (sexual) interactions was greater for girls. While about half of participants reported not experiencing peer bullying, boys more commonly experienced bulling by other boys or girls, and girls by boys only. Among those who had experienced bullying, approximately $40 \%$ reported that this was due to them being a boy vs. girl, or because they acted in a gender non-confirmatory way. Girls were less likely to report physical violence and boys more likely to report violence victimization irrespective of the perpetrator's sex.

\section{Multivariable analyses of selected sexual wellbeing indicators}

Correlations between the five selected sexual wellbeing indicators are shown in Table 3. The rho coefficients of several indicators were low (under \pm 0.15 ) signaling that these are related, yet distinct, constructs of sexual wellbeing.

Results from the multivariable regression models (Tables 4-5) highlighted differential patterns associated with each sexual wellbeing indicator for boys vs. girls. Due to space constraints, only findings from the multivariable models are presented here; results from the bivariate analyses are shown in Appendix Tables 3-4.

\section{Boys}

For boys, the odds of SRHR communication were greater for those living in Denpasar relative to Lampung, and those who reported higher voice and decision-making, as well as romantic and sexual experiences. Meanwhile, rejecting sexual double standard norms was positively associated with living in Semarang, greater educational aspirations, and negatively linked with older age, higher parental connectedness, greater perceived voice, being in a relationship, and sexual experiences. In contrast, the odds of reporting positive body satisfaction were greater for those with high religiosity, romantic and sexual experiences, and lower for those with greater educational aspirations. The odds of perceived self-efficacy to reject unwanted (sexual) advances were higher in Denpasar and Semarang, for those living with both parents and with greater voice; but lower for those in relationships. Freedom from peer violence or bullying was positively associated with high religiosity, and negatively linked with feeling threatened at school, greater perceived decision-making, romantic and sexual experiences (Table 4).

\section{Girls}

For girls, the odds of speaking with others about SRHR were greater for those living in Denpasar or Semarang relative to Lampung, and, in addition, were associated with: older age, greater voice and decision-making, and romantic relationship experiences. Similarly, living in Denpasar or Semarang, greater voice and decision-making were associated with greater self-efficacy to say no; this outcome was also positively associated with higher educational aspirations, and negatively linked with older age, feeling threatened at school and being in a relationship. Positive body satisfaction was also associated with high voice and decisionmaking, as well as with high religiosity, romantic experiences, and living with both parents. In contrast, rejecting the sexual double standard was less common among girls who reported greater decision-making, those living in Denpasar or Semarang, those who had missed schooldays, and had sexual experiences. Similarly, the odds of freedom from peer bullying and violence among girls 
varied by site and decreased with greater perceived voice, romantic and sexual experiences, and perceived threats at school. Whereas, living with both parents and high parental connectedness increased the likelihood of reporting no experiences of bullying or violence (Table 5).

\section{Discussion}

This study adds to the small but growing body of evidence exploring positive aspects of adolescent sexuality. It is one of the first to measure sexual wellbeing from a broad perspective among 10-14-year-olds, especially in an Asian context where sexual norms remain restrictive [22]. Our findings suggest that while boys and girls in these Indonesian settings score high on some aspects of sexual wellbeing (such as body satisfaction), unequal gender attitudes, misconceptions, guilt and uncertainties related to sexuality are common, and self-efficacy to prevent pregnancy is very low. The high levels of sexual guilt and misperceptions confirm the low SRHR knowledge found in the 2017 national DHS study with older youth (ages 15-24-years), where few had received any schoolbased information on family planning [15]. Indeed, previous qualitative studies show how Indonesian parents and young people alike avoid talking about puberty and sexuality due to the perceived irrelevance and taboo of the topics [22, 23].

While comparing our findings to global research is challenging due to the lack of validated measures and inclusion of 10-14-yearolds, it aligns with how a 2018 Ugandan study found that most young adolescents held a positive body image, but endorsement of unequal gender norms was common [24]. The authors also observed differential patterns for boys and girls - confirming our findings that gender differences in healthy sexuality development appear to manifest early in adolescence.

Specifically, we found that girls reported lower SRHR knowledge, poorer body satisfaction, more feelings of guilt, and lower selfefficacy to prevent pregnancy than boys. Voice and decision-making seemed to be especially linked with sexual wellbeing for girls, similar to how research with 10-14-year-olds in other urban poor settings have found perceived agency to correlate with SRH communication [25]. In contrast, boys were more likely to hold gender stereotypical attitudes, less self-efficacy to "say no", and to report having experienced bullying and violence, while simultaneously reporting lower educational aspirations and parental connectedness - both of which were associated with sexual wellbeing.

These differences are likely related to the Indonesian norms around sexuality and gender that considers pre-marital sex and unregulated boy-girl contact as 'dangerous' and 'immoral' [22]. Social norms appears to especially target girls to conform to conventional moral behavior, with boys permitted far greater freedom [26]. However, qualitative research with older Indonesian youth highlights how young men face contesting masculinity norms to both become reliable citizens and family providers, while simultaneously living up to ideals of hegemony and risk-taking [27]. Similarly, qualitative findings from six other GEAS sites illustrates gender norms expecting boys to be tough and not to show emotions, while perceiving girls at greater SRHR risk and in need of protection [28]. Future waves can help elucidate if gender differences persist, and, if so, whether and how they impact (sexual) health and wellbeing.

We also found that romantic relationship involvement was positively linked with both greater SRHR communication and body satisfaction. Although the specific meaning of these 'relationships' is unclear, evidence suggests that they are more social than sexual in nature [29]. In light of findings from previous studies [30], one could hypothesize that having a girlfriend or boyfriend is experienced as a form of "social confirmation," thereby boosting body satisfaction. In contrast, romantic experiences were associated with less ability to reject unwanted advances as well as more violence. This is somewhat expected given the young age and context, where early dating or sexual experiences might be(come) unwanted [8].

\section{Limitations}

There are a number of limitations to our study, including the cross-sectional baseline data which precludes conclusions about causality. The longitudinal design will, however, allow for further exploration of associations over time. The high levels of missing responses may constitute another limitation; we addressed this issue via sensitivity analyses. Given the minimal differences between the full and complete case data sets, we feel that the use of the large sample benefitted the analysis. As in any study about adolescent sexuality, the survey might also have been subject to social desirability bias; we addressed this risk by emphasizing the privacy and voluntary nature of the study. Finally, because the study focused on adolescents in selected schools from three different urban sites, findings are not generalizable within or beyond the Indonesian context. Nonetheless, to our 
knowledge this is the first large-scale quantitative study to assess healthy adolescent sexuality rather than sexual risk using a variety of validated measures in a setting where this topic remains understudied.

\section{Conclusions}

Our findings call for public health interventions that target adolescents, as well as their broader social contexts (including parents) to address restrictive norms related to gender and sexuality [3]. In particular, comprehensive sexuality education (CSE) can play an important role to support adolescent sexual wellbeing by providing evidence-based, contextually and developmentally-appropriate information across different time points [3]. Global evidence shows that when implemented well, CSE can successfully improve adolescent SRHR [12, 31-34] bolstering knowledge, self-efficacy, communication and decision-making [12, 32, 33]. Such education should start early and not only aim at prevention of risk behavior, but to support young people's positive understanding of their own development and build skills to navigate their complex and sometimes contradictory social realities [12, 33, 35]. School-based CSE that addresses gender and power dynamics including harmful masculinity norms [34] may also provide a tool to reduce the relatively high levels of peer bullying and violence found in the current study, especially for boys - which, unless addressed, might manifest as intimate partner violence later in adolescence [36, 37].

In terms of research implications, our results confirm both the importance and complexity of measuring sexual wellbeing in adolescence, being among the first to explore this among the youngest age groups in a low-income country. There is always a desire for simple solutions based on linear relationships between factors, but the present research shows that data rarely align with such simplicity. For example, high decision-making among boys was associated with more SRHR communication, but inversely associated with freedom from violence. Consistent with previous research, greater agency, for example, does not appear to be equally associated with all positive outcomes [21] (e.g. reduced interpersonal violence). Rather, our results confirm sexual wellbeing as a multi-dimensional phenomenon, calling for studies to move beyond traditional outcomes such as unintended pregnancy and HIV/STI to include a broader range of validated measures. Future longitudinal studies will be critical to better understand healthy adolescent sexuality development and could provide more specific direction for designing and evaluating CSE and other adolescent SRHR interventions. We encourage researchers in adolescent SRHR to continue exploring sexual wellbeing across the life-course with representative samples across different cultural settings.

\section{Abbreviations}

SRHR = Sexual and Reproductive Health and Rights

GEAS = Global Early Adolescent Study

SDS= Sexual Double Standard

GST = Gender Stereotypical Traits

GSR $=$ Gender Stereotypical Roles

kNN = K-nearest Neighbor

AIC = Akaike's Information Criteria

DHS = Demographic and Health Survey

CSE $=$ Comprehensive Sexuality Education

HIV= Human Immunodeficiency Virus

STI = Sexually Transmitted Infections

\section{Declarations}




\section{Ethics approval and consent to participate}

The study received ethical approval from the Medical Research and Ethics Committee at the Faculty of Medicine, Public Health and Nursing, University Gadjah Mada, and the Johns Hopkins Bloomberg School of Public Health Institutional Review Board for secondary data analysis.

\section{Consent for publication}

Not applicable.

\section{Availability of data and materials}

The datasets used and/or analysed during the current study are available from the corresponding author on reasonable request

\section{Competing interests}

The authors declare that they have no competing interests.

\section{Funding}

This work was supported by Explore4Action program partners: Rutgers; Rutgers WPF; Center for Reproductive Health, Universitas Gadjah Mada; PKBI Bali; PBKI Jawa Tengah; PKBI Lampung; the Global Early Adolescent Study (GEAS) at the Johns Hopkins Bloomberg School of Public Health, and Karolinska Institutet, with support from the Bill \& Melinda Gates Foundation [INV-008426]. Support for the GEAS study is made possible in part by the United States Agency for International Development (USAID), the World Health Organization (WHO), the David and Lucile Packard Foundation, the Bill and Melinda Gates Foundation, the Oak Foundation, and the United Nations Children's Fund. The funders had no role in study design, data collection, analysis or interpretation of the data.

\section{Author's contributions}

AEK conceptualized the study, conducted the analyses and led the writing of the manuscript. MVR contributed to the study design and wrote sections of the manuscript. AWP supervised the local data collection together with SAW and assisted with the analysis. AP and SAW reviewed and provided input on manuscript drafts.

\section{Acknowledgements}

The authors would like to thank Mengmeng Li at Johns Hopkins Bloomberg School of Public Health for assisting with the multiple imputation of the data, and Professor Robert Wm Blum for manuscript editing. Special thanks to the local research teams, the schools and local advisory committees at the three sites, and to all the adolescents and their parents who participated in this research.

\section{Author's information}

AK is Assistant Professor in Global Sexual and Reproductive Health at the Department of Global Public Health, Karolinska Institutet, Sweden.

AWP is a Research Assistant at Center for Reproductive Health, Universitas Gadjah Mada, Indonesia. 
AP is a Research, Monitoring and Evaluation Officer at Rutgers, Netherlands.

SAW is Professor at the Center for Reproductive Health and Department of Biostatistics, Epidemiology and Population Health, Universitas Gadjah Mada, Indonesia.

MVR is a Senior Researcher at Rutgers, Netherlands.

\section{References}

1. United Nations Population Fund (UNFPA). Programme of action of the International Conference on Population Development. 20th Anniversary ed. New York: UNFPA; 2014.

2. Liang M, Simelane S, Fortuny Fillo G, Chalasani S, Weny K, Salazar Canelos P, et al. The State of Adolescent Sexual and Reproductive Health. Journal of Adolescent Health. 2019;65(6):S3-S15.

3. Chandra-Mouli V, Ferguson BJ, Plesons M, Paul M, Chalasani S, Amin A, et al. The political, research, programmatic, and social responses to adolescent sexual and reproductive health and rights in the 25 years since the International Conference on Population and Development. Journal of Adolescent Health. 2019;65(6):S16-S40.

4. Arbeit MR. What does healthy sex look like among youth? Towards a skills-based model for promoting adolescent sexuality development. Human Development. 2014;57(5):259-86.

5. Harden KP. A Sex-Positive Framework for Research on Adolescent Sexuality. Perspectives on Psychological Science. 2014;9(5):455-69.

6. Landers S, Kapadia F. The Public Health of Pleasure: Going Beyond Disease Prevention. American Journal of Public Health. 2020;110(2):140-1.

7. Tolman DL, McClelland SI. Normative Sexuality Development in Adolescence: A Decade in Review, 2000-2009. Journal of Research on Adolescence. 2011;21(1):242-55.

8. Woog V, Kågesten A. The sexual and reproductive health needs of very young adolescents aged 10-14 in developing countries: what does the evidence show. New York: Guttmacher Institute. 2017.

9. Rostosky SS, Dekhtyar O Fau - Cupp PK, Cupp Pk Fau - Anderman EM, Anderman EM. Sexual self-concept and sexual selfefficacy in adolescents: a possible clue to promoting sexual health? The Journal of Sex Research.45(3):227-86.

10. Thorsen ML. A Latent Class Analysis of Behavioral and Psychosocial Dimensions of Adolescent Sexuality: Exploring Race Differences. Journal of Sex Research.55(1):45-59.

11. Hensel DJ, Fortenberry JD. A multidimensional model of sexual health and sexual and prevention behavior among adolescent women. Journal of Adolescent Health. 2013;52(2):219-27.

12. Constantine NA, Jerman P, Berglas NF, Angulo-Olaiz F, Chou CP, Rohrbach LA. Short-term effects of a rights-based sexuality education curriculum for high-school students: a cluster-randomized trial. BMC Public Health. 2015;15.

13. Kemigisha E, Nyakato VN, Bruce K, Ndaruhutse Ruzaaza G, Mlahagwa W, Ninsiima AB, et al. Adolescents' Sexual Wellbeing in Southwestern Uganda: A Cross-Sectional Assessment of Body Image, Self-Esteem and Gender Equitable Norms. LID 10.3390/ijerph15020372 [doi] LID - 372. (1660-4601 (Electronic)).

14. Wijaya Mulya T. From vulnerable to responsible youth? Indonesian youth resisting the dominant discourse of sexual health. Psychology \& Sexuality. 2019;10(3):248-60.

15. National Population and Family Planning Board (BKKBN), Statistics Indonesia (BPS), Ministry of Health (Kemenkes), ICF. Indonesia Demographic and Health Survey 2017: Adolescent Reproductive Health. Jakarta, Indonesia and Rockville Maryland, USA: BKKBN, BPS, Kemenkes, ICF; 2018.

16. Kågesten A, van Reeuwijk M. Adolescent sexual wellbeing: a conceptual framework. SocArXiv, https://doiorg/1031235/osfio/9as6e. 2021, February 15.

17. UGM Center for Reproductive Health. Early Adolescent's Health in Indonesia: Evidence Base from GEAS-Indonesia, Baseline 2019. Yogyakarta: UGM; 2019.

18. von Elm E, Altman DG, Egger M, Pocock SJ, Gøtzsche PC, Vandenbroucke JP. The Strengthening the Reporting of Observational Studies in Epidemiology (STROBE) statement: guidelines for reporting observational studies. J Clin Epidemiol.

Page $10 / 19$ 
2008;61(4):344-9.

19. Moreau C, Li M, De Meyer S, Vu Manh L, Guiella G, Acharya R, et al. Measuring gender norms about relationships in early adolescence: Results from the global early adolescent study. SSM Popul Health. 2018;7:014-14.

20. Blum R, Li M, Choiryyah I. Body Satisfaction in Early Adolescence: a multi-site comparison. Journal of Adolescent Health. In press.

21. Zimmerman LA, Li M, Moreau C, Wilopo S, Blum R. Measuring agency as a dimension of empowerment among young adolescents globally; findings from the Global Early Adolescent Study. SSM Popul Health. 2019;8:100454.

22. Holzner BM, Oetomo D. Youth, sexuality and sex education messages in Indonesia: issues of desire and control. Reprod Health Matters. 2004;12(23):40-9.

23. Nurachmah E, Yona S, Ismail R, Afiyanti Y, Khariroh S, Surdana IK, et al. Adolescent-parent communication about sexual and reproductive health among junior high school students in five areas with the highest prevalence of HIV in Indonesia: A qualitative study. Enferm Clin. 2019;29 Suppl 2:194-8.

24. Kemigisha E, Nyakato VN, Bruce K, Ndaruhutse Ruzaaza G, Mlahagwa W, Ninsiima AB, et al. Adolescents' Sexual Wellbeing in Southwestern Uganda: A Cross-Sectional Assessment of Body Image, Self-Esteem and Gender Equitable Norms. Int J Environ Res Public Health. 2018;15(2):372.

25. Koenig LR, Li M, Zimmerman LA, Kayembe P, Lou C, Mafuta E, et al. Associations Between Agency and Sexual and Reproductive Health Communication in Early Adolescence: A Cross-cultural, Cross-sectional Study. Journal of Adolescent Health. 2020;67(3):416-24.

26. Smith-Hefner NJ. 'Hypersexed' Youth and the New Muslim Sexology in Java, Indonesia. RIMA: Review of Indonesian and Malaysian Affairs. 2009(1):209-44.

27. Nilan P. Contemporary masculinities and young men in Indonesia. Indonesia and the Malay World. 2009;37(109):327-44.

28. Mmari K, Moreau C, Gibbs SE, De Meyer S, Michielsen K, Kabiru CW, et al. 'Yeah, I've grown; I can't go out anymore': differences in perceived risks between girls and boys entering adolescence. Cult Health Sex. 2018;20(7):787-98.

29. Connolly JA, Mclsaac C. Romantic relationships in adolescence. Handbook of adolescent psychology: Contextual influences on adolescent development, Vol 2, 3rd ed. Hoboken, NJ, US: John Wiley \& Sons, Inc.; 2009. p. 104-51.

30. Markey CN, Markey PM. Romantic relationships and body satisfaction among young women. Journal of Youth and Adolescence. 2006;35(2):256-64.

31. Fonner VA, Armstrong KS, Kennedy CE, O'Reilly KR, Sweat MD. School Based Sex Education and HIV Prevention in Low- and Middle-Income Countries: A Systematic Review and Meta-Analysis. PLOS ONE. 2014;9(3):e89692.

32. Rohrbach LA, Berglas NF, Jerman P, Angulo-Olaiz F, Chou C-P, Constantine NA. A Rights-Based Sexuality Education Curriculum for Adolescents: 1-Year Outcomes From a Cluster-Randomized Trial. Journal of Adolescent Health. 2015;57(4):399-406.

33. UNESCO. Review of the evidence on sexuality education. Report to inform the update of the UNESCO International Technical Guidance on Sexuality Education. Paris: UNESCO; 2016.

34. Haberland N, Rogow D. Sexuality education: emerging trends in evidence and practice. J Adolesc Health. 2015;56(1 Suppl):S15-21.

35. UNESCO. International technical guidance on sexuality education: an evidence-informed approach. Revised edition. Paris: UNESCO; 2018.

36. Lundgren R, Amin A. Addressing Intimate Partner Violence and Sexual Violence Among Adolescents: Emerging Evidence of Effectiveness. Journal of Adolescent Health. 2015;56(1, Supplement):S42-S50.

37. UNESCO, UN Women. Global Guidance on addressing school-related gender-based violence. Paris: UNESC0; 2018.

\section{Tables}


Table 1

Sample characteristics $(N=4309)$

\begin{tabular}{|c|c|c|c|c|}
\hline & Total & Boys & Girls & $p$ \\
\hline Variable & $N=4309$ & $N=2031$ & $N=2278$ & \\
\hline Site & & & & 0.14 \\
\hline Bandar Lampung & 1143 (26.5\%) & $543(26.7 \%)$ & $600(26.3 \%)$ & \\
\hline Denpasar & $1682(39.0 \%)$ & $818(40.3 \%)$ & $864(37.9 \%)$ & \\
\hline Semarang & $1484(34.4 \%)$ & $670(33.0 \%)$ & $814(35.7 \%)$ & \\
\hline \multicolumn{5}{|l|}{ Individual } \\
\hline Age (mean) & $12.2(0.5)$ & $12.2(0.6)$ & $12.1(0.5)$ & $<0.001$ \\
\hline $10-12$ years & 3356 (77.9\%) & $1499(73.8 \%)$ & 1857 (81.5\%) & \\
\hline $13-14$ years & $953(22.1 \%)$ & $532(26.2 \%)$ & $421(18.5 \%)$ & \\
\hline Pubertal onset & & & & $<0.001$ \\
\hline Prepubertal & $310(7.2 \%)$ & $194(9.6 \%)$ & $116(5.1 \%)$ & \\
\hline Pubertal & 3999 (92.8\%) & 1837 (90.4\%) & $2162(94.9 \%)$ & \\
\hline Religion & & & & 0.55 \\
\hline Islam & 2725 (63.2\%) & $1264(62.2 \%)$ & $1461(64.1 \%)$ & \\
\hline Hinduism & 1477 (34.3\%) & 715 (35.2\%) & $762(33.5 \%)$ & \\
\hline Christian/other & $91(2.5 \%)$ & $43(2.5 \%)$ & $48(2.4 \%)$ & \\
\hline Religiosity & & & & $<0.001$ \\
\hline Low & $618(14.3 \%)$ & $248(12.2 \%)$ & $370(16.2 \%)$ & \\
\hline High & 3691 (85.7\%) & 1783 (87.8\%) & 1908 (83.8\%) & \\
\hline Perceived voice (median, IQR) & $3.0(2.6,3.4)$ & $2.9(2.3,3.3)$ & $3.0(2.7,3.4)$ & $<0.001$ \\
\hline Low & $2461(57.1 \%)$ & $1284(63.2 \%)$ & $1177(51.7 \%)$ & $<0.001$ \\
\hline High & $1848(42.9 \%)$ & $747(36.8 \%)$ & $1101(48.3 \%)$ & \\
\hline Decision-making (median, IQR) & $3.0(2.5,3.2)$ & $3.0(2.3,3.2)$ & $3.0(2.5,3.2)$ & 0.003 \\
\hline Low & $2828(65.6 \%)$ & $1365(67.2 \%)$ & $1463(64.2 \%)$ & 0.039 \\
\hline High & $1481(34.4 \%)$ & $666(32.8 \%)$ & $815(35.8 \%)$ & \\
\hline Relationship status & & & & $<0.001$ \\
\hline Never in relationship & $2581(59.9 \%)$ & $1118(55.0 \%)$ & $1463(64.2 \%)$ & \\
\hline Ever but not currently & $994(23.1 \%)$ & $445(21.9 \%)$ & $549(24.1 \%)$ & \\
\hline Currently in relationship & $734(17.0 \%)$ & $468(23.0 \%)$ & $266(11.7 \%)$ & \\
\hline Ever non-coital sexual activities & & & & $<0.001$ \\
\hline No & 3089 (71.7\%) & $1383(68.1 \%)$ & $1706(74.9 \%)$ & \\
\hline Yes & $1220(28.3 \%)$ & $648(31.9 \%)$ & $572(25.1 \%)$ & \\
\hline Ever sexual intercourse & & & & $<0.001$ \\
\hline
\end{tabular}




\begin{tabular}{|c|c|c|c|c|}
\hline & Total & Boys & Girls & $p$ \\
\hline No & 4255 (98.7\%) & $1982(97.6 \%)$ & 2273 (99.8\%) & \\
\hline Yes & $54(1.3 \%)$ & $49(2.4 \%)$ & $5(0.2 \%)$ & \\
\hline \multicolumn{5}{|l|}{ Family } \\
\hline Main caregiver & & & & 0.027 \\
\hline Mother & 3830 (88.9\%) & $1772(87.2 \%)$ & 2058 (90.3\%) & \\
\hline Father & $240(5.6 \%)$ & $129(6.4 \%)$ & $111(4.9 \%)$ & \\
\hline Sibling & $21(0.5 \%)$ & $12(0.6 \%)$ & $9(0.4 \%)$ & \\
\hline Grandparent & $119(2.8 \%)$ & $67(3.3 \%)$ & $52(2.3 \%)$ & \\
\hline Other & $99(2.3 \%)$ & $51(2.5 \%)$ & $48(2.1 \%)$ & \\
\hline Living with & & & & $<0.001$ \\
\hline Both parents & 3695 (85.7\%) & 1717 (84.5\%) & $1978(86.8 \%)$ & \\
\hline One parent & $386(9.0 \%)$ & $171(8.4 \%)$ & $215(9.4 \%)$ & \\
\hline Grandparents/other & $228(5.3 \%)$ & $143(7.0 \%)$ & $85(3.7 \%)$ & \\
\hline Parental connectedness & & & & 0.007 \\
\hline Low & $507(11.8 \%)$ & $254(12.5 \%)$ & $253(11.1 \%)$ & \\
\hline Somewhat & $1024(23.8 \%)$ & $517(25.5 \%)$ & $507(22.3 \%)$ & \\
\hline High & 2778 (64.5\%) & $1260(62.0 \%)$ & $1518(66.6 \%)$ & \\
\hline \multicolumn{5}{|l|}{ School/community } \\
\hline Educational aspirations & & & & $<0.001$ \\
\hline$\leq$ Junior high & $128(3.0 \%)$ & $88(4.3 \%)$ & $40(1.8 \%)$ & \\
\hline Senior high/dipl. & $784(18.2 \%)$ & $513(25.3 \%)$ & $271(11.9 \%)$ & \\
\hline University & $3322(77.1 \%)$ & 1389 (68.4\%) & $1933(84.9 \%)$ & \\
\hline Other & $75(1.7 \%)$ & $41(2.0 \%)$ & $34(1.5 \%)$ & \\
\hline School days missed last month & & & & $<0.001$ \\
\hline None & 3038 (70.5\%) & $1363(67.1 \%)$ & $1675(73.5 \%)$ & \\
\hline $1-2$ days & $1114(25.9 \%)$ & $580(28.6 \%)$ & $534(23.4 \%)$ & \\
\hline 3 or more days & $157(3.6 \%)$ & $88(4.3 \%)$ & $69(3.0 \%)$ & \\
\hline Ever felt threatened at school & & & & $<0.001$ \\
\hline No & $3558(82.6 \%)$ & $1627(80.1 \%)$ & $1931(84.8 \%)$ & $<0.001$ \\
\hline Yes & $751(17.4 \%)$ & $404(19.9 \%)$ & $347(15.2 \%)$ & \\
\hline \multicolumn{5}{|l|}{ Access to social media } \\
\hline No & $295(6.8 \%)$ & $161(7.9 \%)$ & $134(5.9 \%)$ & $<0.01$ \\
\hline Yes & $4014(93.2)$ & $1870(92.1 \%)$ & $2144(94.1 \%)$ & \\
\hline
\end{tabular}


Table 2

Prevalence of sexual wellbeing indicators for boys and girls in Indonesia

\begin{tabular}{|c|c|c|c|c|c|}
\hline Variable & Category & $\begin{array}{l}\text { Total }(\mathrm{N}= \\
\text { 4309) }\end{array}$ & $\begin{array}{l}\text { Boys }(N= \\
2031)\end{array}$ & $\begin{array}{l}\text { Girls }(N= \\
2278)\end{array}$ & $p$ \\
\hline & & $\mathrm{n}(\%)$ & $\mathrm{n}(\%)$ & $\mathrm{n}(\%)$ & \\
\hline & & mean (SD) & mean (SD) & mean (SD) & \\
\hline \multicolumn{6}{|l|}{ Sexual literacy and communication } \\
\hline Knowledge about HIV & $\begin{array}{l}\text { Mean (SD) range } \\
1-4\end{array}$ & $0.9(1.1)$ & $1.1(1.1)$ & $0.7(1.0)$ & $<.001$ \\
\hline $\begin{array}{l}\text { Knowledge about pregnancy and } \\
\text { contraceptives }\end{array}$ & $\begin{array}{l}\text { Mean (SD) range } \\
1-6\end{array}$ & $1.7(1.5)$ & $2.0(1.6)$ & $1.5(1.4)$ & $<.001$ \\
\hline \multirow[t]{3}{*}{ Overall SRHR knowledge } & $\begin{array}{l}\text { Mean (SD) range } \\
1-10\end{array}$ & $2.6(2.3)$ & $3.1(2.4)$ & $2.2(2.2)$ & $<.001$ \\
\hline & Low (<50\% correct) & $\begin{array}{l}3364 \\
(78.1 \%)\end{array}$ & $\begin{array}{l}1456 \\
(71.7 \%)\end{array}$ & $\begin{array}{l}1908 \\
(83.8 \%)\end{array}$ & $<$. \\
\hline & $\begin{array}{l}\text { High }(\geq 50 \% \\
\text { correct) }\end{array}$ & $945(21.9 \%)$ & $575(28.3 \%)$ & $370(16.2 \%)$ & \\
\hline \multirow[t]{2}{*}{ SRHR communication } & No & $\begin{array}{l}1371 \\
(31.8 \%)\end{array}$ & $633(31.2 \%)$ & $738(31.8 \%)$ & $<.387$ \\
\hline & Yes & $\begin{array}{l}2938 \\
(68.2 \%)\end{array}$ & $\begin{array}{l}1398 \\
(68.8 \%)\end{array}$ & $\begin{array}{l}1540 \\
(67.6 \%)\end{array}$ & \\
\hline \multirow[t]{4}{*}{ SRHR topics ever discussed* } & $\begin{array}{l}\text { Body } \\
\text { changes/puberty }\end{array}$ & $\begin{array}{l}2182 \\
(74.3 \%)\end{array}$ & $964(69.0 \%)$ & $\begin{array}{l}1218 \\
(79.1 \%)\end{array}$ & $<0.001$ \\
\hline & Sexual relations & $884(30.1 \%)$ & $581(41.6 \%)$ & $303(19.7 \%)$ & $\begin{array}{l}< \\
0.001\end{array}$ \\
\hline & Pregnancy & $\begin{array}{l}1127 \\
(38.4 \%)\end{array}$ & $593(42.4 \%)$ & $534(34.7 \%)$ & $\begin{array}{l}< \\
0.001\end{array}$ \\
\hline & Contraceptives & $649(22.1 \%)$ & $410(29.3 \%)$ & $239(15.5 \%)$ & $<.001$ \\
\hline \multicolumn{6}{|l|}{ Gender attitudes } \\
\hline Sexual double standard & $\begin{array}{l}\text { Mean (SD) range } \\
1-5\end{array}$ & $2.7(1.0)$ & $2.7(1.0)$ & $2.7(1.0)$ & 0.92 \\
\hline Gender-stereotypical traits & $\begin{array}{l}\text { Mean (SD) range } \\
1-5\end{array}$ & $3.9(0.7)$ & $3.9(0.7)$ & $3.8(0.7)$ & $<.001$ \\
\hline Gender-stereotypical roles & $\begin{array}{l}\text { Mean (SD) range } \\
1-5\end{array}$ & $3.9(1.0)$ & $3.9(1.0)$ & $3.8(0.9)$ & 0.054 \\
\hline \multirow[t]{2}{*}{$\begin{array}{l}\text { Ok to tease a boy/girl who behaves like } \\
\text { opposite gender }\end{array}$} & Do not agree & $\begin{array}{l}3118 \\
(72.4 \%)\end{array}$ & $\begin{array}{l}1375 \\
(67.7 \%)\end{array}$ & $\begin{array}{l}1743 \\
(76.5 \%)\end{array}$ & $\begin{array}{l}< \\
0.001\end{array}$ \\
\hline & Agree & $\begin{array}{l}1191 \\
(27.6 \%)\end{array}$ & $656(32.3 \%)$ & $535(23.5 \%)$ & \\
\hline \multicolumn{6}{|l|}{ Comfort with body and emerging sexuality } \\
\hline Body satisfaction & $\begin{array}{l}\text { Mean (SD) range } \\
1-5\end{array}$ & $3.6(0.8)$ & $3.8(0.8)$ & $3.5(0.8)$ & $<$. \\
\hline \multicolumn{6}{|c|}{ *Among those who ever discussed SRHR ( $N=2938$ total, $N=1398$ boys, $N=1540$ girls) } \\
\hline
\end{tabular}




\begin{tabular}{|c|c|c|c|c|c|}
\hline Variable & Category & $\begin{array}{l}\text { Total }(\mathrm{N}= \\
\text { 4309) }\end{array}$ & $\begin{array}{l}\text { Boys }(N= \\
2031)\end{array}$ & $\begin{array}{l}\text { Girls }(N= \\
2278)\end{array}$ & $p$ \\
\hline & Negative & $\begin{array}{l}1258 \\
(29.2 \%)\end{array}$ & $466(22.9 \%)$ & $792(34.8 \%)$ & $\dot{0.001}$ \\
\hline & Positive & $\begin{array}{l}3051 \\
(70.8 \%)\end{array}$ & $\begin{array}{l}1565 \\
(77.1 \%)\end{array}$ & $\begin{array}{l}1486 \\
(65.2 \%)\end{array}$ & \\
\hline \multirow[t]{3}{*}{ Comfort with pubertal development } & Do not agree & $760(17.6 \%)$ & $455(22.4 \%)$ & $305(13.4 \%)$ & $\begin{array}{l}<.001 \\
0.00\end{array}$ \\
\hline & Neutral & $661(15.3 \%)$ & $221(10.9 \%)$ & $440(19.3 \%)$ & \\
\hline & Agree & $\begin{array}{l}2888 \\
(67.0 \%)\end{array}$ & $\begin{array}{l}1355 \\
(66.7 \%)\end{array}$ & $\begin{array}{l}1533 \\
(67.3 \%)\end{array}$ & \\
\hline \multirow[t]{2}{*}{ Feelings of guilt about sexuality } & Low & $731(17.0 \%)$ & $482(23.7 \%)$ & $249(10.9 \%)$ & $\begin{array}{l}<.001 \\
0.00\end{array}$ \\
\hline & High & $\begin{array}{l}3578 \\
(83.0 \%)\end{array}$ & $\begin{array}{l}1549 \\
(76.3 \%)\end{array}$ & $\begin{array}{l}2029 \\
(89.1 \%)\end{array}$ & \\
\hline \multirow[t]{3}{*}{ Normal to be curious about love/sexuality } & Do not agree & $\begin{array}{l}1220 \\
(28.3 \%)\end{array}$ & $487(24.0 \%)$ & $733(32.2 \%)$ & $\dot{0} 001$ \\
\hline & Agree & $\begin{array}{l}2337 \\
(54.2 \%)\end{array}$ & $\begin{array}{l}1204 \\
(59.3 \%)\end{array}$ & $\begin{array}{l}1133 \\
(49.7 \%)\end{array}$ & \\
\hline & Do not know & $752(17.5 \%)$ & $340(16.7 \%)$ & $412(18.1 \%)$ & \\
\hline \multicolumn{6}{|l|}{ Perceived relational self-efficacy } \\
\hline \multirow[t]{2}{*}{ Communicate romantic feelings } & Low & $\begin{array}{l}2559 \\
(59.4 \%)\end{array}$ & $\begin{array}{l}1029 \\
(50.7 \%)\end{array}$ & $\begin{array}{l}1530 \\
(67.2 \%)\end{array}$ & $\begin{array}{l}< \\
0.001\end{array}$ \\
\hline & High & $\begin{array}{l}1750 \\
(40.6 \%)\end{array}$ & $\begin{array}{l}1002 \\
(49.3 \%)\end{array}$ & $748(32.8 \%)$ & \\
\hline \multirow[t]{2}{*}{ Say "no" to unwanted interaction } & Low & $\begin{array}{l}1861 \\
(43.2 \%)\end{array}$ & $\begin{array}{l}1006 \\
(49.5 \%)\end{array}$ & $855(37.5 \%)$ & $\dot{0.001}$ \\
\hline & High & $\begin{array}{l}2448 \\
(56.8 \%)\end{array}$ & $\begin{array}{l}1025 \\
(50.5 \%)\end{array}$ & $\begin{array}{l}1423 \\
(62.5 \%)\end{array}$ & \\
\hline \multirow[t]{2}{*}{ Prevent pregnancy } & Low & $\begin{array}{l}3767 \\
(87.4 \%)\end{array}$ & $\begin{array}{l}1682 \\
(82.8 \%)\end{array}$ & $\begin{array}{l}2085 \\
(91.5 \%)\end{array}$ & $\begin{array}{l}<.001 \\
0.00\end{array}$ \\
\hline & High & $542(12.6 \%)$ & $349(17.2 \%)$ & $193(8.5 \%)$ & \\
\hline \multicolumn{6}{|l|}{ Freedom from peer bullying and violence } \\
\hline \multirow[t]{3}{*}{ Bullied by peers in last 6 months } & No & $\begin{array}{l}2155 \\
(50.0 \%)\end{array}$ & $963(47.4 \%)$ & $\begin{array}{l}1192 \\
(52.3 \%)\end{array}$ & $\begin{array}{l}< \\
0.001\end{array}$ \\
\hline & $\begin{array}{l}\text { Yes, by both } \\
\text { boys/girls }\end{array}$ & $\begin{array}{l}1721 \\
(39.9 \%)\end{array}$ & $960(47.3 \%)$ & $761(33.4 \%)$ & \\
\hline & $\begin{array}{l}\text { Yes, by opposite sex } \\
\text { only }\end{array}$ & $433(10.0 \%)$ & $108(5.3 \%)$ & 325 (14.3\%) & \\
\hline
\end{tabular}

*Among those who ever discussed SRHR ( $N=2938$ total, $N=1398$ boys, $N=1540$ girls $)$

\pm Among those reporting bullying in the past 6 months $(N=2154$ total, $N=1068$ boys, $N=1086)$ 


\begin{tabular}{|c|c|c|c|c|c|}
\hline Variable & Category & $\begin{array}{l}\text { Total }(\mathrm{N}= \\
\text { 4309) }\end{array}$ & $\begin{array}{l}\text { Boys (N = } \\
2031)\end{array}$ & $\begin{array}{l}\text { Girls (N = } \\
2278)\end{array}$ & $p$ \\
\hline \multirow[t]{2}{*}{ Reason for bullying ${ }^{ \pm}$} & Due to gender & $881(40.9 \%)$ & $455(42.6 \%)$ & $426(39.2 \%)$ & 0.111 \\
\hline & Other reason & $\begin{array}{l}1273 \\
(59.1 \%)\end{array}$ & $613(57.4 \%)$ & $660(60.8 \%)$ & \\
\hline \multirow[t]{3}{*}{ Physical violence from peers in last 6 months } & No & $\begin{array}{l}3587 \\
(83.2 \%)\end{array}$ & $\begin{array}{l}1525 \\
(75.1 \%)\end{array}$ & $\begin{array}{l}2062 \\
(90.5 \%)\end{array}$ & $<.001$ \\
\hline & $\begin{array}{l}\text { Yes, by both } \\
\text { boys/girls }\end{array}$ & $510(11.8 \%)$ & $376(18.5 \%)$ & $134(5.9 \%)$ & \\
\hline & $\begin{array}{l}\text { Yes, by opposite sex } \\
\text { only }\end{array}$ & $212(4.9 \%)$ & $130(6.4 \%)$ & $82(3.6 \%)$ & \\
\hline \multirow[t]{2}{*}{$\begin{array}{l}\text { Any peer violence (combined bullying or } \\
\text { physical) }\end{array}$} & No & $882(43.4 \%)$ & $\begin{array}{l}1174 \\
(51.5 \%)\end{array}$ & $\begin{array}{l}2056 \\
(47.7 \%)\end{array}$ & $<.001$ \\
\hline & Yes & $\begin{array}{l}1149 \\
(56.6 \%)\end{array}$ & $\begin{array}{l}1104 \\
(48.5 \%)\end{array}$ & $\begin{array}{l}2252 \\
(52.3 \%)\end{array}$ & \\
\hline \multicolumn{6}{|c|}{ *Among those who ever discussed SRHR ( $N=2938$ total, $N=1398$ boys, $N=1540$ girls) } \\
\hline \multicolumn{6}{|c|}{ \pm Among those reporting bullying in the past 6 months $(N=2154$ total, $N=1068$ boys, $N=1086)$} \\
\hline
\end{tabular}

Table 3

Correlations between five different indicators for sexual wellbeing (rho)

\begin{tabular}{|c|c|c|c|c|}
\hline & SRHR communication & Disgaree with SDS & Body satisfaction & Self-efficacy to say no \\
\hline Disagree with SDS & $-0.1701^{\star}$ & & & \\
\hline Body satisfaction & $0.2247 *$ & $-0.0924^{*}$ & & \\
\hline Self-efficacy to say no & $0.1669 *$ & $-0.0535^{\star}$ & -0.0350 & \\
\hline No bullying/violence & $-0.2102^{*}$ & $0.1720 *$ & -0.0301 & $-01154^{\star}$ \\
\hline \multicolumn{5}{|c|}{${ }^{\star} \mathrm{p}<0.05,{ }^{* *} \mathrm{p}<0.01,{ }^{* \star *} \mathrm{p}<0.001$} \\
\hline
\end{tabular}


Table 4

Multivariable analysis of selected sexual wellbeing indicators: Boys $(N=2031)$

\begin{tabular}{|c|c|c|c|c|c|c|c|c|c|c|}
\hline \multirow[b]{2}{*}{ Variable } & \multicolumn{2}{|c|}{$\begin{array}{l}\text { Ever talked } \\
\text { about SRHR }\end{array}$} & \multicolumn{2}{|c|}{$\begin{array}{l}\text { Disagree with } \\
\text { sexual double } \\
\text { standard }\end{array}$} & \multicolumn{2}{|c|}{$\begin{array}{l}\text { High body } \\
\text { satisfaction }\end{array}$} & \multicolumn{2}{|c|}{$\begin{array}{l}\text { High self-efficacy to } \\
\text { say no }\end{array}$} & \multicolumn{2}{|c|}{ No bullying/violence } \\
\hline & $\mathrm{aOR}$ & $\begin{array}{l}95 \% \\
\mathrm{Cl}\end{array}$ & $\mathrm{aOR}$ & $\begin{array}{l}95 \% \\
\mathrm{Cl}\end{array}$ & $\mathrm{aOR}$ & $\begin{array}{l}95 \% \\
\mathrm{Cl}\end{array}$ & $\mathrm{aOR}$ & $\begin{array}{l}95 \% \\
\mathrm{Cl}\end{array}$ & $\mathrm{aOR}$ & $95 \% \mathrm{Cl}$ \\
\hline \multicolumn{11}{|l|}{$\begin{array}{l}\text { Site (ref: } \\
\text { Lampung) }\end{array}$} \\
\hline Denpasar & $2.54 * \star \star$ & $\begin{array}{l}1.97- \\
3.27\end{array}$ & 1.14 & $\begin{array}{l}0.90^{-} \\
1.45\end{array}$ & & & $1.72^{\star \star \star}$ & $\begin{array}{l}1.37- \\
2.15\end{array}$ & 0.86 & $0.68-1.08$ \\
\hline Semarang & 0.93 & $\begin{array}{l}0.72- \\
1.18\end{array}$ & $1.73^{\star \star \star}$ & $\begin{array}{l}1.34- \\
2.24\end{array}$ & & & $1.77^{\star \star \star}$ & $\begin{array}{l}1.40- \\
2.23\end{array}$ & $0.71^{\star \star \star}$ & $0.55-0.90$ \\
\hline $\begin{array}{l}\text { Age } 13-14 \\
\text { (ref: } 10-12 \\
\text { years) }\end{array}$ & & & $0.76^{\star \star}$ & $\begin{array}{l}0.61- \\
0.94\end{array}$ & & & 0.83 & $\begin{array}{l}0.67- \\
1.02\end{array}$ & & \\
\hline $\begin{array}{l}\text { High religiosity } \\
\text { (ref: low) }\end{array}$ & & & & & $1.40 *$ & $\begin{array}{l}1.04- \\
1.90\end{array}$ & & & $1.36^{*}$ & $1.02-1.81$ \\
\hline $\begin{array}{l}\text { High voice (ref: } \\
\text { low) }\end{array}$ & $1.34 * \star$ & $\begin{array}{l}1.07- \\
1.66\end{array}$ & $0.78^{*}$ & $\begin{array}{l}0.64- \\
0.95\end{array}$ & 1.21 & $\begin{array}{l}0.96- \\
1.53\end{array}$ & $1.35^{\star \star *}$ & $\begin{array}{l}1.12- \\
1.62\end{array}$ & & \\
\hline $\begin{array}{l}\text { High decision- } \\
\text { making (ref: } \\
\text { low) }\end{array}$ & $1.35^{\star \star}$ & $\begin{array}{l}1.08- \\
1.69\end{array}$ & & & 1.18 & $\begin{array}{l}0.93- \\
1.50\end{array}$ & & & $0.75^{\star \star \star}$ & $0.61-0.91$ \\
\hline \multicolumn{11}{|l|}{$\begin{array}{l}\text { Relationship } \\
\text { status (ref: } \\
\text { never) }\end{array}$} \\
\hline $\begin{array}{l}\text { Ever but not } \\
\text { currently }\end{array}$ & 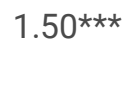 & $\begin{array}{l}1.16- \\
1.94\end{array}$ & 0.95 & $\begin{array}{l}0.74- \\
1.23\end{array}$ & $1.36^{*}$ & $\begin{array}{l}1.04- \\
1.77\end{array}$ & 1.15 & $\begin{array}{l}0.92- \\
1.44\end{array}$ & 0.92 & $0.72-1.16$ \\
\hline $\begin{array}{l}\text { Currently in } \\
\text { relationship }\end{array}$ & 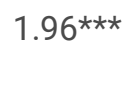 & $\begin{array}{l}1.48- \\
2.60\end{array}$ & $0.73^{*}$ & $\begin{array}{l}0.57- \\
0.95\end{array}$ & $2.11^{\star \star \star}$ & $\begin{array}{l}1.58- \\
2.82\end{array}$ & $0.79 *$ & $\begin{array}{l}0.63- \\
0.98\end{array}$ & $0.56^{\star \star \star}$ & $0.43-0.72$ \\
\hline $\begin{array}{l}\text { Ever sexual } \\
\text { activity (ref: } \\
\text { no) }\end{array}$ & $1.97^{\star \star \star}$ & $\begin{array}{l}1.54- \\
2.50\end{array}$ & $0.68^{\star \star \star}$ & $\begin{array}{l}0.55- \\
0.85\end{array}$ & & & & & $0.56^{\star \star \star}$ & $0.45-0.70$ \\
\hline $\begin{array}{l}\text { Live with both } \\
\text { parents (ref: } \\
\text { no) }\end{array}$ & & & & & & & $1.31 \star$ & $\begin{array}{l}1.02- \\
1.68\end{array}$ & $1.28^{ \pm}$ & $0.99-1.66$ \\
\hline \multicolumn{11}{|l|}{$\begin{array}{l}\text { Parental } \\
\text { connectedness } \\
\text { (ref: low) }\end{array}$} \\
\hline Somewhat & $1.33^{ \pm}$ & $\begin{array}{l}0.96- \\
1.86\end{array}$ & $0.50 * \star \star$ & $\begin{array}{l}0.35- \\
0.71\end{array}$ & & & & & & \\
\hline High & $1.32^{ \pm}$ & $\begin{array}{l}0.98- \\
1.78\end{array}$ & $0.65^{\star \star}$ & $\begin{array}{l}0.47- \\
0.90\end{array}$ & & & & & & \\
\hline $\begin{array}{l}\text { University } \\
\text { aspirations } \\
\text { (ref: no) }\end{array}$ & & & $1.32 * \star$ & $\begin{array}{l}1.07- \\
1.62\end{array}$ & $0.75^{\star}$ & $\begin{array}{l}0.60- \\
0.95\end{array}$ & 1.12 & $\begin{array}{l}0.92- \\
1.36\end{array}$ & & \\
\hline $\begin{array}{l}\text { Felt threatened } \\
\text { at school (ref: } \\
\text { no) }\end{array}$ & & & $0.80^{ \pm}$ & $\begin{array}{l}0.63- \\
1.02\end{array}$ & & & & & $0.28^{\star \star \star}$ & $0.22-0.37$ \\
\hline$\star * * p<0.001, * * p$ & $0.01, * p$ & $.05, \pm p$ & 0.10 & & & & & & & \\
\hline
\end{tabular}


Table 5

Multivariable analysis of selected sexual wellbeing indicators: Girls (N=2278)

\begin{tabular}{|c|c|c|c|c|c|c|c|c|c|c|}
\hline \multirow[b]{2}{*}{ Variable } & \multicolumn{2}{|c|}{$\begin{array}{l}\text { Ever talked } \\
\text { about SRHR }\end{array}$} & \multicolumn{2}{|c|}{$\begin{array}{l}\text { Disagree with } \\
\text { sexual double } \\
\text { standard }\end{array}$} & \multicolumn{2}{|c|}{$\begin{array}{l}\text { High body } \\
\text { satisfaction }\end{array}$} & \multicolumn{2}{|c|}{$\begin{array}{l}\text { High self-efficacy tc } \\
\text { say no }\end{array}$} & \multicolumn{2}{|c|}{ No bullying/violence } \\
\hline & $\mathrm{aOR}$ & $\begin{array}{l}95 \% \\
\mathrm{Cl}\end{array}$ & $\mathrm{aOR}$ & $\begin{array}{l}95 \% \\
\mathrm{Cl}\end{array}$ & $\mathrm{aOR}$ & $\begin{array}{l}95 \% \\
\mathrm{Cl}\end{array}$ & $\mathrm{aOR}$ & $\begin{array}{l}95 \% \\
\mathrm{Cl}\end{array}$ & $\mathrm{aOR}$ & $95 \% \mathrm{Cl}$ \\
\hline \multicolumn{11}{|l|}{$\begin{array}{l}\text { Site (ref: } \\
\text { Bandar } \\
\text { Lampung) }\end{array}$} \\
\hline Denpasar & $3.75^{\star \star \star}$ & $\begin{array}{l}2.95- \\
4.77\end{array}$ & $0.66^{* * *}$ & $\begin{array}{l}0.52- \\
0.84\end{array}$ & 1.25 & $\begin{array}{l}1.00- \\
1.57\end{array}$ & $2.76^{\star \star \star}$ & $\begin{array}{l}2.21- \\
3.45\end{array}$ & $0.76^{*}$ & $0.61-0.96$ \\
\hline Semarang & $1.57 * \star \star$ & $\begin{array}{l}1.25- \\
1.97\end{array}$ & $0.70 * \star \star$ & $\begin{array}{l}0.55- \\
0.89\end{array}$ & 0.86 & $\begin{array}{l}0.69- \\
1.07\end{array}$ & $2.49 * \star *$ & $\begin{array}{l}1.99- \\
3.12\end{array}$ & $0.70 * \star \star$ & $0.56-0.88$ \\
\hline $\begin{array}{l}\text { Age 13-14 } \\
\text { (ref: } 10-12 \\
\text { years) }\end{array}$ & $1.35^{\star}$ & $\begin{array}{l}1.06- \\
1.73\end{array}$ & & & & & $0.75^{\star \star}$ & $\begin{array}{l}0.60- \\
0.94\end{array}$ & & \\
\hline $\begin{array}{l}\text { High religiosity } \\
\text { (ref: low) }\end{array}$ & $1.22^{ \pm}$ & $\begin{array}{l}0.96- \\
1.57\end{array}$ & & & $1.43^{\star \star \star}$ & $\begin{array}{l}1.13- \\
1.81\end{array}$ & & & & \\
\hline $\begin{array}{l}\text { High voice (ref: } \\
\text { low) }\end{array}$ & $1.37 * \star \star$ & $\begin{array}{l}1.13- \\
1.67\end{array}$ & $0.84^{ \pm}$ & $\begin{array}{l}0.69- \\
1.01\end{array}$ & $1.27 \star \star$ & $\begin{array}{l}1.06- \\
1.52\end{array}$ & $1.51^{\star \star \star}$ & $\begin{array}{l}1.25- \\
1.82\end{array}$ & $0.75^{\star \star \star}$ & $0.62-0.90$ \\
\hline $\begin{array}{l}\text { High decision- } \\
\text { making (ref: } \\
\text { low) }\end{array}$ & $1.41^{\star \star \star}$ & $\begin{array}{l}1.15- \\
1.73\end{array}$ & $0.80 *$ & $\begin{array}{l}0.66- \\
0.97\end{array}$ & $1.40 * \star \star$ & $\begin{array}{l}1.15- \\
1.70\end{array}$ & $1.44^{\star \star \star}$ & $\begin{array}{l}1.19- \\
1.75\end{array}$ & $0.83^{ \pm}$ & $0.69-1.00$ \\
\hline \multicolumn{11}{|l|}{$\begin{array}{l}\text { Relationship } \\
\text { status (ref: } \\
\text { never) }\end{array}$} \\
\hline $\begin{array}{l}\text { Ever but not } \\
\text { currently }\end{array}$ & $1.49 * \star \star$ & $\begin{array}{l}1.18- \\
1.87\end{array}$ & & & $1.36 * \star$ & $\begin{array}{l}1.09- \\
1.70\end{array}$ & 1.10 & $\begin{array}{l}0.89- \\
1.37\end{array}$ & $0.67 * * \star$ & $0.54-0.83$ \\
\hline $\begin{array}{l}\text { Currently in } \\
\text { relationship }\end{array}$ & 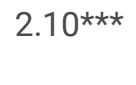 & $\begin{array}{l}1.52- \\
2.90\end{array}$ & & & $1.43^{*}$ & $\begin{array}{l}1.05- \\
1.94\end{array}$ & $0.63^{* * *}$ & $\begin{array}{l}0.48- \\
0.83\end{array}$ & $0.68 * \star$ & $0.51-0.91$ \\
\hline $\begin{array}{l}\text { Ever sexual } \\
\text { activity (ref: } \\
\text { no) }\end{array}$ & & & $0.79 *$ & $\begin{array}{l}0.64- \\
0.97\end{array}$ & $1.23^{ \pm}$ & $\begin{array}{l}0.99- \\
1.54\end{array}$ & & & $0.71 * \star \star$ & $0.57-0.87$ \\
\hline $\begin{array}{l}\text { Live with both } \\
\text { parents (ref: } \\
\text { no) }\end{array}$ & & & & & $1.32 *$ & $\begin{array}{l}1.03- \\
1.71\end{array}$ & $1.27^{ \pm}$ & $\begin{array}{l}0.98- \\
1.64\end{array}$ & $1.33^{*}$ & $1.03-1.72$ \\
\hline \multicolumn{11}{|l|}{$\begin{array}{l}\text { Parental } \\
\text { connectedness } \\
\text { (ref: low) }\end{array}$} \\
\hline Somewhat & 1.14 & $\begin{array}{l}0.82- \\
1.59\end{array}$ & 0.87 & $\begin{array}{l}0.63- \\
1.20\end{array}$ & & & & & 1.19 & $0.86-1.65$ \\
\hline High & $1.28^{ \pm}$ & $\begin{array}{l}0.95- \\
1.73\end{array}$ & 1.10 & $\begin{array}{l}0.82- \\
1.47\end{array}$ & & & & & $1.58 * * \star$ & $1.18-2.11$ \\
\hline $\begin{array}{l}\text { University } \\
\text { aspirations } \\
\text { (ref: no) }\end{array}$ & & & & & & & $1.34^{\star}$ & $\begin{array}{l}1.05- \\
1.71\end{array}$ & & \\
\hline
\end{tabular}




\begin{tabular}{|c|c|c|c|c|c|c|c|c|}
\hline \multirow[b]{2}{*}{$\begin{array}{l}\geq 1 \\
\text { schooldays } \\
\text { missed (ref: } \\
\text { none) }\end{array}$} & \multirow[t]{2}{*}{$\begin{array}{l}\text { Ever talked } \\
\text { about SRHR }\end{array}$} & \multicolumn{2}{|c|}{$\begin{array}{l}\text { Disagree with } \\
\text { sexual double } \\
\text { standard }\end{array}$} & \multirow[t]{2}{*}{$\begin{array}{l}\text { High body } \\
\text { satisfaction }\end{array}$} & \multicolumn{2}{|c|}{$\begin{array}{l}\text { High self-efficacy to } \\
\text { say no }\end{array}$} & \multicolumn{2}{|c|}{ No bullying/violence } \\
\hline & & $0.78^{\star \star}$ & $\begin{array}{l}0.63- \\
0.95\end{array}$ & & & & $0.84^{ \pm}$ & $0.69-1.03$ \\
\hline $\begin{array}{l}\text { Felt threatened } \\
\text { at school (ref: } \\
\text { no) }\end{array}$ & & & & & 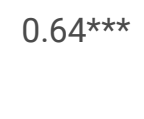 & $\begin{array}{l}0.51- \\
0.82\end{array}$ & 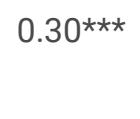 & $0.23-0.39$ \\
\hline
\end{tabular}

\section{Figures}

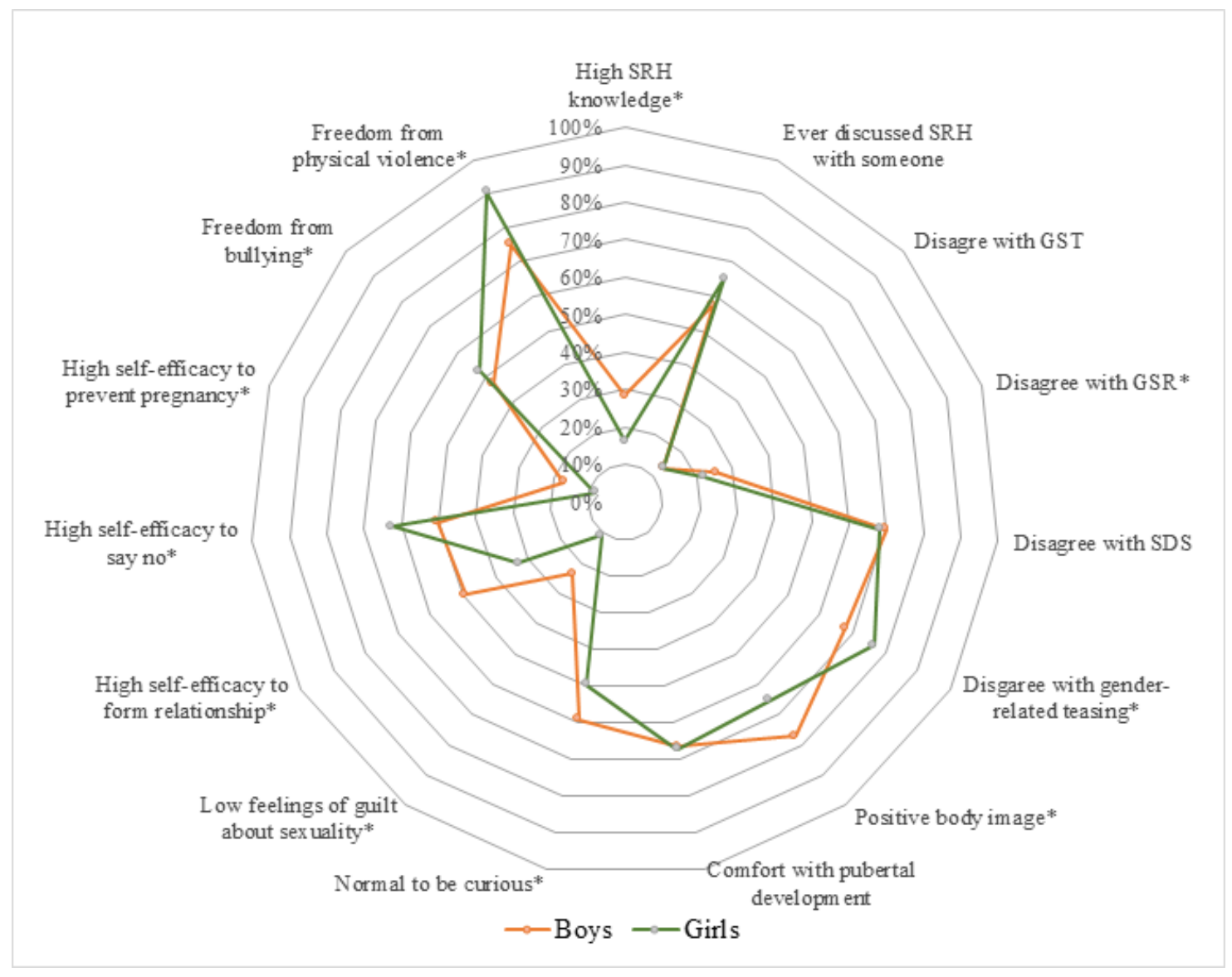

Figure 1

Prevalence of sexual wellbeing indicators among boys and girls in three Indonesian sites. ${ }^{*} \mathrm{p}<0.05$

\section{Supplementary Files}

This is a list of supplementary files associated with this preprint. Click to download.

- AppendixTables14.docx 